\title{
TEACHING ENGLISH AS A LOCAL CONTENT IN THE FOURTH GRADE STUDENTS OF SDN BOGOREJO MERAKURAK TUBAN
}

\author{
Ali Fauzi \\ Institut Agama Islam Nahdlatul Ulama (IAINU) Tuban \\ Email: alifauzi@stitmatuban.ac.id
}

\begin{abstract}
English is an international language used by the people all over the world, therefore to master English-speaking, writing, reading and listening especially for educated people is a must. Knowing this, Indonesian government prepares early and declares that English should be taught as compulsory local content subject in the Elementary school. It is good idea because very young children are easily able to understand English. The government introduces English as a compulsory local content subject taught since they are in the Elementary school throughout Indonesia in order that after they graduate from Elementary school, they then continue to learn it until they graduate from University and have the mentioned skills.

That is why, the researcher is interested in conducting the English teaching research at SDN Bogorejo Merakurak Tuban by choosing the title "Teaching English as a Local Content in the Fourth Grade Students of SDN Bogorejo Merakurak Tuban. The researcher wants to know and describes how she teaches them, what she does, what materials she prepares, and what is the students attitude towards the teaching of English. The result of this study is expected to be able to give an important contribution on the development of teaching English strategy that can support the development of teaching and learning English.

This research is qualitative research in form of case study. The researcher takes only one class-the fourth class students of SDN Bogorejo Merakurak Tuban as the object of research. The approach of the research is phenomenological approach in which the researcher observes and interprets the facts based on the phenomena in the classroom during the teaching of English although it is may be subjective. The researcher also finds the data from many literatures to get theory and and principle as the secondary data used as a means of analyzing it. The method of research he uses is descriptive-qualitative which means that he just describes his finding on the teaching of English. The subject of the research is the students of four class of SDN Bogorejo Merakurak Tuban and the number of it is 24 students.

The result of the research is that teacher at SDN Bogorejo Merakurak Tuban has taught the students successfully. The Researcher does the research since the students get into the classroom and study through the model of Luring since the first week of September 2020. The teacher prepares the material well and applied many kinds of strategy to motivate students to learn English diligently. After studying English, the students now become so enthusiastic that they study by themselves at home because of their own will.
\end{abstract}

Key words: Teaching, English, Local Content, Fourth Grade Students. 


\section{INTRODUCTION}

In this period, English is used in all aspects of life either as a means of communication through speaking or writing. By mastering English, people can easily know the development of many kinds of fields in all the countries in the world. English is not only needed for those who want to get better jobs and positions but also for those who want to get scholarship in the higher educational strata in foreign countries. It can be understood since a lot of scholarships are offered to the candidates who have good mastery of English both spoken and written. That is why, each candidate should be able to fulfill the qualifications of English as required for getting scholarship or better jobs. Knowing the importance of English skill in all aspects of life, Indonesian government prepares early and declares that English should be taught as compulsory local content subject in the Elementary school.

As we know that English has also been used as second language in many countries. Even the citizens of many Asian and African countries have used English as a means of communication in certain events. This is because the countries have started teaching English since the students are in Pre-Elementary school. This is different with the educational system of Indonesia that starts teaching English legally from junior high school for three years then it continues to the next level in senior high school for three years. So they have studied English for 6 years continuously and most of them are lack of practicing English, in return they cannot communicate in English spoken or written well.

As a good idea to overcome the problem and to improve the proficiency of English among the young learners is by teaching English earlier at elementary school. We know from the experience that very young children are easily able to understand English. It means that if the students can study English earlier in a natural situation, the acquisitions of the materials they learnt will be almost the same as the native speakers. Therefore, the government introduces English as a local content subject taught since they are in the Elementary school as it is in line with the 1994 curriculum. It is not compulsory but suggested that all elementary schools throughout Indonesia have to teach English to their students. However, in reality there have been many schools adopting the teachers of English regardless of the limited of human resources they have. In big cities like Jakarta and Surabaya, almost all elementary schools have taught English as their local content subject for a long time.

That is why, the researcher is interested in conducting the English teaching research at SDN Bogorejo Merakurak Tuban by choosing the title "Teaching English as a Local Content in the Fourth Grade Students of SDN Bogorejo Merakurak Tuban as the title of this research report. The researcher wants to know and describes how she teaches them, what she does, what materials she 
prepares, and what is the students attitude towards the teaching of English. The result of this study is expected to be able to give an important contribution on the development of teaching English strategy that can support the development of teaching and learning English. The researcher also hopes that it will be useful as a reference to the next researcher who is interested in further research of young learners.

It is informed that the number of students at SDN Bogorejo Merakurak Tuban is 115 students consisting of class one 13 students, class two is 19 students, class three is 18 students, class four is 24, class five is 17 and class six is 24 students. This research is limited on the teaching of English as a local content at the 24 students of the fourth grade of SDN Bogorejo Merakurak Tuban. He chooses the class because, the number of the students is more than the others and the class is relatively middle of the all. The teaching of English as the work of a teacher (Hornby, 1995:1225) need to be researched in order to know how far is the the process. English in this case is only the local content which means that the materials of lesson is not given by national curriculum but by the local school (Hornby, 1995:230). Since the students are still children, the teacher must know the charactersistic of the young learner that is elementary school students who are six to twelve years old. They are by nature different from adult. They like playing and moving whereas adults seems reluctant to move and regard playing as childish. So the teacher should know which one the children like and dislike is. She also has to know and use the appropriate curriculum in which it is the content of the subject and the skills that comprise an educational program. The emphasis of a curriculum depends on philosophical, social, and cultural processes that effect the school in terms of the board society and specific community. Besides the elements above, teacher must also uses media. Kasbolah (1993) classifies teaching media into three categories (1) Audio media (2) Visual media (3) Audio Visual Media. Audio media is media that can only be heard. The media are usually used to teach listening comprehension skills. Audio media include Radio, Tape recorder, Cassettes and language laboratory. Visual media is media that can be seen and touched by the students. These media include pictures, Photograph etc. Audio Visual media is the kind of media thatcan be seen and heard by the students such as TV, Film, LCD etc.

\section{RESEARCH METHOD}

This research is qualitative research in form of case study. Qualitative research uses approach which orientates on the natural symptom, so it is relatively related to the phenomena in the classroom in this case is in the classroom. The researcher takes only one class-the fourth students of SDN Bogorejo Merakurak Tuban as the object of research. The approach of the research is phenomenological approach in which the researcher observes and interprets the facts 
based on the phenomena in the classroom during the teaching of English although it is may be subjective (Arifin, 1994: 46-47). The researcher also finds the data from many literatures to get theory and and principle as the secondary data used as a means of analyzing it (Arikunto, 2002: 23). Meanwhile the method of research he uses is descriptive-qualitative which means that he just describes his finding on the teaching of English (Bogdan and Biklen in Moleong, 2017: 3-10). It means that the researcher describes all he finds in based on the data of observation. The subject of the research is the students of four class of SDN Bogorejo Merakurak Tuban and the number of it is 24 students. For the sake of the observation, besides the enough number to researh, he selects the class based on the assumption and the agreement between the researcher and the head master.

In fact, there are two kinds of data of this research (1) the qualitative data is the SDN instructional Materials, and the Instructional activities. (2) The quantitative data is about the achievement of the students. However, the researcher only discuss the data qualitatively in form of the description of the teaching of English. It is positive that this research is qualitative research and the instrument of research is the researcher himself as the key instrument. In this regard, this research is nealy based on the observation as it is said by Arikunto (1998:235) that observation is looking at the evidences, movement, or process directly. So the purpose of the observation in this research is to record the activities performed by both the teacher and the students. After the researcher collects the research data, he then analyzesb it. The data collected through the documentation are teaching preparation, the instructional material, and if possible the students' achievement. They were presented in descriptive way.

\section{TEACHING ENGLISH AS A LOCAL CONTENT IN THE FOURTH GRADE STUDENTS OF SDN BOGOREJO MERAKURAK TUBAN}

\section{Teaching English to the Young Learners}

Teaching English for the young learners may include many skills like speaking, listening, writing and reading but the real thing the teacher can do is to see the condition of the students first. Speaking skill is an important thing in the process of language learning, especially for elementary students. Learning to speak English is not easy for the students in Elementary school, so that the teacher has to make the class atmosphere pleasant and enjoyable because usually children like to play games and have fun. Halliwell (1992: 6) stated, "Children have an enormous capacity for finding and making fun." Besides speaking, other aspects in teaching English are grammar, vocabulary and pronunciation. Grammar is very important, but sometimes it is difficult to stand back and take a clear look at it. Language without grammar would certainly leave us seriously handicapped. In fact, the process of learning English in a formal education system is not sufficient 
for mastering a foreign language. Even though the students have been learning English for years, they cannot use English efficiently as a means of communication. They cannot use it for daily practice. It is difficult for them to acquire the four language skills. Of course, it is difficult for them to master it. They do not get used to the habit of learning foreign language. They cannot speak simple English, memorize the vocabulary, and write correct sentences in a relatively short time. The most crucial thing is the lack of time and also do not have a special place to facilitate practicing their knowledge they have got. Those are the main causes of the failure.

It is sure that to learn English is a complex problem, need process and needs serious learning. Some reasons why learning English requires long time are that learning foreign language is a process that needs long period of time. It cannot be done in a short time or in one moment. It indeed requires a process. If English is learned in longer time, the student will have the opportunity to acquire it gradually. Besides it, the English teacher should not only be concerned with developing one aspect but also with those three aspects altogether because they make the key to understand the meaning of what the speakers say. One of the key elements of success in foreign class is the possibility of that class to be not only an instant of learning, but also a moment of fun. To make it real, the teacher can support the students' motivation. Tosta (2001 :27) said that the humor makes the class atmosphere more pleasant, increases interaction among the teacher and students and makes learning more meaningful and enjoyable. It is useful tool to get students' attention, to motivate learners, and to create pleasant situation on students. Meanwhile, the elements of teaching the teacher must have are as follows:

\section{a. Curriculum}

When a school or an institution decides curriculum, the following questions will help determine a curriculum: 1) what is the purpose or mission of the education necessary to serve the plan of the organization. 2) What goals for education necessary to serve the plan? 3) How can the instruction be categorized and organized to accomplish the goals?. The most frequently cited statement curriculum planning was formulated by Tyler (1949). It consists of four elements, originally stated as follows: 1) What organizational purpose should the school seek to attain? 2) How can educational experiences be provided that are likely to achieve this purpose? 3) How can experiences be effectively organized? 4) How can we determine whether these purpose is being attained?. Seeking answers to these questions, Tyler suggests the requirements of the examination of the three primary sources: characteristics of the learners, the contemporary society, and the nature of subject to be taught.

\section{b. Instructional Material.}


The instructional material is one of the components needed in the process teaching especially in teaching English. In this section, the researcher presents the text book and the instructional media.

\section{Textbooks}

Choosing a book for whole class is very difficult. Usually the text book is decided by the team teaching and it has advantages when the text book is determined by the team of English teachers. One of the advantages is there will be a strong basis to make eventual decision if they make an analysis on the book. So it is better that the teachers can choose what actually the good materials for the students together. Rajan ((1995) states that we have to make an evaluation of the text book to be able to choose the appropriate materials for the students. There are some basic considerations for choosing good textbook as follows:

\section{- The content.}

- Whether they are varieties of topics according to the learners' level and needs.

- Whether they are arranged in a logical sequence on the basis of the topic/them

- Whether there is a summary on the topic content.

- Whether there is a clear subsection and consistently differentiated by the spatial organization of the text.

- Whether there are reviews on the skills previously taught.

- The vocabulary and the structure.

- whether the number of new words in every level is suitable for the student' level needs

- Whether there is any gradation in the vocabulary introduced.

- Whether the materials provide for practice in word formation and vocabulary development.

- Whether the vocabularies introduced in one lesson reinforced in later lesson.

- Whether the vocabulary list at the end of the unit/books.

- The activities/exercises/tasks.

- Whether they are interesting or not.

- Whether they have variety and a purpose.

- Whether they provide opportunities for a natural use of language.

- Whether the activities, tasks, and exercises provide the students enough practice in all the skills. 
- Whether the activities, tasks, and exercises provide for varying learning arrangements such as pair-work, and individual works.

- Whether the instruction for the activities, tasks, and exercise are simple, and clear.

- $\quad$ The supportive materials.

- Whether there are additional workbooks or worksheets provided with the materials/textbook.

- Whether there are tapes for pronunciation practice or listening comprehension.

- Whether there are any appropriate supplementary materials available.

\section{The Instructional Media}

Instructional Media is the instruments that are used to make the communication effective so that the teaching objective can be achieve totally. There are a lot of ways to help the students understand structures, sentences, phrases and text. This is also effective to help the students acquire language skills, in which the they can use the language passively and actively. Kasbolah (1993) classifies teaching media into three categories (1) Audio media (2) Visual media (3) Audio Visual Media. Audio media is media that can only be heard. The media are usually used to teach listening comprehension skills. Audio media include Radio, Tape recorder, Cassettes and language laboratory. Visual media is media that can be seen and touched by the students. These media include pictures, Photograph etc. Audio Visual media is the kind of media thatcan be seen and heard by the students such as TV, Film, LCD etc. Brown et.al (1983) states that teachers should be able to select the instructional media from among the numerous media resources of general orientation, those that are coming closest to meeting local requirement, at the same time, meeting other stated of excellent media.

\section{The Basic English Curriculum of Elementary Education}

The basic curriculum of elementary education states that English is as one of the local content subjects. English is considered important for the purpose of absorbing the science, technology, culture and developing the relationship with foreign countries. English may be given when the school need it. It should be supported by the existence of qualified teachers, based on the statement, English is applied as the local content subject. Local content subject can be applied based on the suitability with the environment condition and need. It is allowed when it does not reduce the content of the national curriculum. The local content subject is aimed at developing the students' ability to understand oral and written messages and simple idiomatic expression (elementary education Curriculum, 1994).

\section{- The English Local content Curriculum}


More specifically, the 1994 English curriculum conveys the basic course outline of the implementation of English as a local content subject. The purpose of teaching of English as a local content subject is to give the opportunity to the elementary school students to get the knowledge and to develop English in order to anticipate the development of science and technology (Depdikbud, 1994). The objective is that after graduated from the elementary schools, the students have skill of reading, listening, speaking, and writing English in simple pattern based on their development level and interest within their vocabulary achievement level at about 500 words. The scope of the material of English in elementary school include simple listening, reading, speaking skills and the focus is on listening, and speaking. The guideline is that the approach in the teaching learning process is the meaning fullness approach. It means that all the language components should be given in the context, so the meaning will be clear, furthermore for the teaching learning process the four language skills should be developed integrated

\section{The Teacher's Role}

Elementary school teacher should try to work and understand each characteristic of students. They should be aware that children are affected by cultural influences (pollard, 1994). They still depend on their teacher, their peers, and also their family in making their decisions. The teacher should cooperate to think their actions. Otherwise, the students will suffer. Here teachers play some important roles in teaching learning activity. Allen and Vellete (in Kasbollah, 1993) states that the teacher is the main figure in the classroom because he is the one who arranges all the class activities. He should set up a conductive situation that prevents student from getting bored. The teacher should be a component one because his competence will enable him to present the materials in an appropriate way. The teacher should arrange appropriate strategy for the teaching learning activities. Therefore, Kasbolah (1993) proposes some requirements that should be obtained by a teacher as follows; 1) a teacher should be a good facilitator for the students. He should help the students if they need it. He should arouse the students' responses by asking some questions. He should explain the lesson in brief and clear manners. 2) a teacher should be able to present the teaching material appropriately. 3) a teacher should be able to become a good model for his students. 4) a teacher should have a sufficient knowledge about linguistic and culture of the target language. 5) a teacher should be active in choosing the methods and techniques for teaching. Kasbolah (1998) also states that teachers should have four charaters as follows: (1) Knowledge, (2) Skills, (3) Personal qualities, and (4) Professionalism. In fact, not all teachers fulfill the criteria above. An English teacher should set up a conductive situation that prevents students from assumption that English teacher is a 'scary' subject. A teacher should be a total teacher. He should 
not be seen as more technicians who conducts the job that is delivering the knowledge but as a teacher who involves his skill, values, and expertise in it (Hargeaves, 1994).

\section{The Technique of Teaching}

The technique of teaching is very important component in the process of studying because it can help the teacher in developing the class activities in order to become pleasant class and enjoyable. As stated by Richard and Rodgers (1963) that technique is the implementation, which actually takes a place in the classroom. Based on the children potential to learn the English pronunciation, Rahmayanti (in Cahyono, 1997) also proposes suitable techniques to develop children communicative ability. These are Song, dialogue, Games and story tellings.

\section{The Scope of Teaching English}

The scope of teaching English is the English skill. There are four skills in studying English. The teaching material given to the students are including Speaking, Writing, Listening and Reading.

\section{a. Speaking}

Speaking is the oldest and most universal way for human beings to express their thoughts and feelings. Studying speaking is also included as one of the programs given at SDN Bogorejo Merakurak Tuban. In this case, the teachers have various materials in trying to improve the speaking skills of the students such as memorizing, vocabulary, conversation, telling story, some quizzes, game, singing and drama. Even though the students are still under 11 years, the students are hoped to be able to understand the material and can speak English and the teachers are hoped to make the material easy to understand and not boring.

\section{b. Writing}

Besides speaking, the students of SDN Bogorejo Merakurak Tuban are also taught writing. The capacity of the material of writing is adjusted to the ability of the students such as writing simple sentences and paragraphs. The target is that the students are able to make sentences and even paragraphs well.

\section{c. Listening}

It does not complete yet if the students have only two language skills-Speaking and Writing, so in the process of learning English, the students of SDN Bogorejo Merakurak Tuban are also taught Listening material. Because of the young age, the students are only taught enjoyable and fresh listening materials to avoid boredom like listening to children's songs, simple dictation and sometimes watching English cartoon movies.

\section{d. Reading}

Reading is a crucial need for everyone especially for the students of SDN Bogorejo Merakurak Tuban, so reading is also studied. The students are really hoped to be creative 
students after getting the basic material of reading. The materials are based on the materials in the book used and focused on the fluency of reading on the pronunciation.

\section{Research Data}

Those four language-skills are based on the data we got from the pre-observation as the skills the teachers teaches to the students. The data is presented as follows:

\section{a. The Activities}

There are two models of activities done in the process of teaching English at SDN Bogorejo Merakurak Tuban. They are indoor activities and outdoor activities. Indoor activities mean the study activities are done in the classroom and Outdoor activities mean the study activities are done out of the classroom. There are three steps that are usually used by the teachers in doing activities in the classroom.

\section{1) Pre activities}

Based on the data of observation, the teacher of SDN Bogorejo, Merakurak-Tuban usually greets students saying "Assalamu'alaikum" and then "Good morning Class. How are you today?". The students answer the question, "We are fine and you?". The teacher answers "I am fine, too and we are fine. Thank God." Before, the lesson begins, the teacher instructs the students to pray together. She asks them saying "Let's begin our lesson today by reciting Basmallah together." and the students recite Bismillaahirrahmaanirrahiim. Finishing to recite Basmallah, then the teacher calls the students' names one by one based on the attendance list, then the students say "present" if the student is present and the others say "absent" if they any student who does not attend the class.

\section{2) Middle-activities}

In teaching, the teacher must use the method. Method is the way how teacher teaches students. There are many kinds of methods the teacher can use and it depends on the needs. They are; direct method, audo-lingual method, and total physical response method. Direct method is the method desinged to encourage the students to speak directly without paying much attention to structure. In this method the teacher has a great role in correcting the students' mistake; the students can improve their structure in accordance with the mistake they have made. The simple idea behind the direct method is that the learners learn a foreign language by hearing it spoken and enjoying in conversation. Other language skills such as reading and writing can be developed later. The principle of the direct method is as follows: a) Classroom instruction was conducted exclusively in the target language; b) Only everyday vocabulary and sentences were taught; c) Oral communication skills were built up in a carefully in organized around question and answer exchanges between 
teachers and students in small intensive class; d) Grammar was taught inductively; e) New teaching points were taught through modeling and practice; f) Concrete vocabulary was taught through demonstration, objects and picture: g) Both speech and listening comprehension were taught; and h) Correct pronunciation and grammar were emphasized. The advantages of this method are that the students will be skillful in listening comprehension and have good pronunciation and can manage many vocabularies. The disadvantage of this method is that it is not effective for big class and needs a skillful teacher in pronunciation and avoids of using native language all time so this method will be dangerous for the students who have limited vocabulary.

The Audio-lingual Method (ALM) was firmly grounded in linguistic and psychological theory. The characteristics of the ALM are: (1) new material is presented in the dialog form. (2) There is dependent on mimicry, memorization of short phrase and over learning. (3) Structured are sequenced by means of contrastive analysis and taught one at time. (4) Structural patterns are taught using repetitive drills. (5) There is a little or no grammatical explanation. Grammar is taught by an inductive analogy rather than by deductive explanation. (6) Vocabulary is strictly limited and learned in context. (7) There is much use of tapes, language labs, and visual aids. (8) Great importance is attached to pronunciation. (9) Very little use of mother tongue by teachers is permitted. (10) Successful responses are immediately reinforces. (11) There is great effort to get students to produce error-free utterances. (12) There is a tendency to manipulate language and disregard content.

Total physical response Method TPR combined a number of other insights in its rationale. Principles of child language acquisition were important. Children, in learning their first language, appear to do a lot of listening before they speak, and that their listening is accompanied by physical responses reaching, garbing, moving, looking and so forth. He also gave some attention to right brain learning. Motor activity is a right brain function that should proceed left brain language processing. Language classes were often the locus of too much anxiety, so he wised to devise a method that was as stress-free as possible, where learners would not feel overtly self conscious and defensive. The TPR classroom, then, was one in which students did a great deal of listening and acting. The teacher was very directive in orchestrating a performance: "The instructor is the director of a stage play in which the students are the actors. Typically, TPR heavily utilized the imperative mood, even into more advanced proficiency levels. Commands were easy way to get learners to move about and to loosen up: Open the window, Close the door, Stand up, sit down, Clean the board, Sweep the floor, Give it to Mary, and so on. No verbal response was necessary. 
More complex syntax could be incorporated in to the imperative: Show me your new blue pencil box, Walk slowly to the window and hold it. Humor is easy to introduce: Walk quickly to the door and jump, Put your toothbrush in your bag. Interrogative was also easily dealt with: Where is the book? Who is john? (Students were pointed to the book or to John). Eventually students, one by one, would feel comfortable enough to venture verbal responses to questions, then ask to the questions themselves, and to continue the process. Like every other methods, TPR also had its limitations. It seemed to be especially effective in the beginning level of language proficiency, but it lost its distinctiveness as learners advanced in their competence. In a TPR classroom, after the student overcome their fear of speaking out, classroom conversation and other activities proceeded as in almost any other communicative language classroom. In TPR writing and reading activities, students are limited to spinning of from the oral work in the classroom. Its appeal to dramatic or theatrical nature of language learning was attractive. But soon teachers' needs for spontaneity and unrehearsed language must be met.

It is shown in the data of observation that the main method that is frequently used by the teacher is Speech method especially in giving introduction and explanation to the topic. The teacher explains the lesson in accordance with the topic at the time. Sometimes the teacher also asks the students to sing a song, for instance, when they have to learn about color. The teacher also uses the supportive materials and tells the students some stories for them. Sometimes the teacher also gives some quizzes and games. The children like them very much. Then for reading activity, the most frequent technique is reading aloud. He asks students one or two of the students to read loudly to be the model for the others. Then the other students have their turn. For writing, usually the teacher dictates his students some simple sentences. Sometimes he also asks the students to write their experience, something they like or dislike. The common activities are individual, whole class activities, or sometimes pair work and group work. Nearly eighty-five percent English-Indonesian is used as a means of communication in the process of teaching and learning. It proves that the teacher really knows the level of English competence of the students. When they want to ask something to the teacher, they try to use their English although it is sometimes combined with Indonesian. Frequently the students are approached by the teacher any time when the students get any difficulties in understanding the lessons. For example: When the students do class work, the teacher walks around the class to know whether the students had any difficulty in understanding the instruction of the question or not. Usually the teacher also punishes the students if the students break the rules of the school, for instance 
the students are obliged to memorize and to call minimally 15 vocabularies if they come late for 5 minutes. They are also asked to look for some vocabularies around the class and to call them if the students come late more than 5 minutes.

\section{3) The last activities}

Before leaving the classroom, the teacher usually concludes the instructional materials she has presented. She also tells the students the material she will discuss for the next meeting. The teacher can manage the time allocation available for each meeting. Before she leaves for the classroom, she prepares the time to conclude the materials she has presented.

\begin{tabular}{|c|c|c|c|}
\hline No & Activities & Material & Content \\
\hline 1 & Indoor & $\begin{array}{l}\text { Grammar } \\
\text { Writing } \\
\text { Listening and } \\
\text { Speaking }\end{array}$ & $\begin{array}{l}\text { Before beginning the class, the teacher greets } \\
\text { the students saying "Assalamu'alaikum, Good } \\
\text { morning class, how are you today?" The } \\
\text { teacher usually opens the class, in English } \\
\text { saying "let's begin our lesson by reading } \\
\text { Basmallah together". When she closes the } \\
\text { class, she also says, "let's close the lesson by } \\
\text { saying, Hamdallah together." } \\
\text { The students study tenses, S. Present T, Past T, } \\
\text { and Future T, in form of simple sentences, } \\
\text { alphabet and greeting. } \\
\text { The teacher dictates the students some simple } \\
\text { English sentences then the students write it } \\
\text { down in their books. } \\
\text { The teacher gets the students to make couple } \\
\text { and practice speaking of some simple } \\
\text { sentences that the teacher has taught to them. } \\
\text { After finishing the lesson, the teacher } \\
\text { concludes the lessons and announces to the } \\
\text { students about the next lesson. }\end{array}$ \\
\hline & Out door & $\begin{array}{l}\text { Pre } \\
\text { Playing Games }\end{array}$ & $\begin{array}{l}\text { Before playing games and singing songs the } \\
\text { teacher usually greets students saying } \\
\text { "Assalamu'alaikum, good morning, how are } \\
\text { you today?. Then she says "let's open the class } \\
\text { by reciting Basmallah together". Then she } \\
\text { instructs the students to play games like Spider } \\
\text { man, Couching a mouse and etc. While playing } \\
\text { games the students are also invited to sing } \\
\text { songs, such song like Brother John, So what U } \\
\text { say?, a pretty lady etc are their songs. } \\
\text { After playing games and sing songs, the } \\
\text { teacher concludes and gives motivation to the } \\
\text { students. }\end{array}$ \\
\hline
\end{tabular}




\section{4) The Material}

The main material used by the teacher of SDN Bogorejo Merakurak Tuban is the text book entitle "Gemar Belajar Bahasa Inggris" published by PT Edumedia. The book is quite complete in term of activities, the vocabularies, the structures, and the illustration presented. The textbook consists of 44 pages. This text book has pictures and varied exercises. It uses English and Indonesia as the medium of instruction.

\section{a) The Textbook and the Techniques of Presenting Materials}

As we know that the learners of English at Elementary schools are still under 12 years old. It means that the students are still young and even they are still in childhood. Children are very energetic and enthusiastic learners, so the content of the textbook should be mainly developed on various kinds of activities to keep the learners always in fresh condition.

\section{b) The Textbook and the Principle of Writing a Textbook}

The relationship between the textbook and the principle of writing a textbook is as follows:

\section{- The content}

The learners will be introduced to basic grammar, such as present, etc in this book. Beside that it has various kinds of topics, according to the learner's level and needs.

\section{- The vocabulary and Structure}

The book consists of sufficient vocabularies for each unit. Moreover, the various kinds of activities enable the students to increase their vocabulary more than they require. Furthermore, the vocabularies are provided in the context, so that students are able to practice how to use the words in sentences. The vocabulary list would help the students to increase the student ability in arranging sentences. In this book list vocabularies are provided at the final page of the book.

\section{b. The activities}

The four language skills are developed integrated at the activities of the book. The materials presented in an interesting way to attract the children. Various kinds of activities are interesting and suitable with the children's characteristic. The instructions are given in the simple English and Indonesian. Using the text book, English is fun rather than a heavy subject because the various kind of activities are provided, so the teachers can choose any activities she likes based on the activities in the book. For instance if the students like puzzle very much, instead of puzzle in the book he can make his own. 


\section{c. The Instructional Media}

The media used in the process of teaching-learning at SDN Bogorejo Merakurak Tuban is sufficient based on the need of the elementary school learners. Real objects around the children are the first media. Surrounding the classroom in where the students are studying English, written some vocabularies to make the students easy and enjoy studying English. Accompanied by the teacher, sometimes the students are also given an occasion to study out of the class to avoid boredom, over there the students are given many kinds of enjoying activities. Besides in natural media the teacher also sometimes introduces the students to study English .at language laboratory. The observation of using the teaching media shows that some kinds of media are important instruments to be used and interesting for students because studying at a real natural can keep their memory.

\section{d. The Instructional Activities}

In this term, the researcher describes about Pre activities, whilst activities, and post activities.

\section{1) Pre Activities}

Based on the data of observation, the teacher of SDN Bogorejo merakurak Tuban usually begins the lesson by greeting “Assalamu'alaikum. Good morning boys and girls, how are you today?". She then gives an instruction in English to begin lesson saying "Let's Open our lesson today by reciting Basmallah or Suratul Fatihah together." Then, the teacher calls the students one by one based on the attendance list provided, and the students say "present" if the student is present and the other say "absent" if they are any students do not attend the class.

\section{2) Whilst-activities}

It is shown in the data of observation that the main technique that is frequently used by the teacher is giving explanation. The teacher explains the lesson in accordance with the topic at the time. Sometimes the teacher also asks the students to sing a song, for instance, when they have to learn about color. The teacher also uses the supportive materials and tells the students some stories for them. Sometimes the teacher also gives some quizzes and games. The children like them very much. Then for reading activity, the most frequent technique is reading aloud. He asks one or two of the students to read in a loud voice to be the model for the others. Then the other students have their turn. For writing, usually the teachers dictate his students some simple sentences. Sometimes he also asks the students to write their experience, something they like or dislike. The common activities are individual, whole class activities, or sometimes pair work and group work. 
Nearly fifty percent English-Indonesian is used in the process of teaching learning. It proved that the teacher really had language discipline in the classroom. It also happened with the students. When they wanted to ask something to the teacher, they tried to use their English although it was sometimes combined with Indonesian. Frequently the students are approached by the teacher any time the students get any difficulties in understanding the lessons. For example: When the students did class work, the teacher walked around the class to know whether the students had any difficulty in understanding the instruction of the question or not. After doing the class work. Usually the teacher also punishes the students if the students break the rules of the school, for instance: the students are obliged to memorize minimally 15 vocabularies if the students came late for 5 minutes. Looking for some vocabularies around the class then being memorized if the students come late more than 5 minutes.

\section{3) Post-activities}

Before leaving the classroom usually the instructional materials that had been presented are concluded by the teacher. The material that will be discussed for the next meeting is also told to the students. The teacher can manage the time allocation available for each meeting. $\mathrm{He}$ has enough time to conclude the materials presented before she left the classroom then they teacher conclude the material.

\section{Students' attitude toward the Teaching of English}

The researcher also gives the questionnaire to the students to know the students' attitude toward the teaching of English.

Table of Percentages of students on the English Teaching

\begin{tabular}{|c|l|c|c|}
\hline \multirow{2}{*}{ No } & \multicolumn{1}{|c|}{ Item } & \multicolumn{2}{c|}{$\%$} \\
\cline { 2 - 4 } & & Yes & No \\
\hline 1 & The students like English & 22 & 2 \\
2 & English is difficult & 7 & 17 \\
3 & The teacher explanation is clear and understandable & 20 & 4 \\
4 & The activities are interesting & 21 & 3 \\
5 & The students are bored with the lesson & 6 & 18 \\
6 & The students do the home work & 24 & 0 \\
7 & The students are afraid of English & 2 & 22 \\
8 & The students want to be able to speak English & 24 & 0 \\
9 & The students take a private course & 15 & 9 \\
10 & The students like English beginning from the elementary & 19 & 5 \\
& school & & \\
11 & The students feel necessary to learn English & 24 & 0 \\
12 & The students learn how to speak English at home & 21 & 3 \\
13 & The students learn English by them selves at home & 22 & 2 \\
14 & The students like watching the English film & 15 & 9 \\
15 & The students are interested in listening the English song & 10 & 14 \\
\hline
\end{tabular}


In the table above, the researcher describes the students' problems and the result of the students' questionnaire. They are: (1) Most of the students like English (90\%); (2) Some of them think that English is difficult (34\%); (3) Most of the students agree that the teachers' explanation is clear and understandable (86\%); (4) They also agree that the activities in the teaching learning process are interesting (70\%); (5) The students are bored with the lesson (15\%) (6) A lot of students do their home work (100\%); (7) Some of the students are afraid English (5\%); (8) The students want to be able to speak English (100\%); (9) The students take a private course (66\%) (10) the students like English beginning from the elementary school (70\%) (11) The students feel necessary to learn English (100\%); (12) The students learn how to speak English at home (73\%) (13) the students learn English by them selves at home (89 \%) (14) The students like watching the English film (68\%) (15) The students are interested in listening the English song (40\%)

\section{CONCLUSION}

Based on the research findings described previously, the researcher concludes as follows:

1. There are two kinds of instructional material used by the teacher. They are Text book and the instructional media.

2. The textbook and the technique of presenting material to the young learners have been adjusted. The content of the textbook has been in accordance with the need of the young learners and has been fit with the principle of writing. the content, the vocabulary and structure and the activities of the textbook have been adjusted with the need and the characteristic of young learners.

3. The instructional media used is the natural media that is all things existing surrounding the environment of the place of study. Beside that audio and audio visual are also provided as the media of teaching learning process.

4. There are three kinds of instructional activities described. These are; Pre activity, where the teacher usually gives some kinds of greeting to the students such as "Assalamu'alaikum, Good Morning" and also opening the lesson by using English language "Let's begin our lesson by reciting Basmallah or Al-fatihah together".

5. The following is in the whilst activities the teacher explains the lesson by using English language even though only $50 \%$ combined with Indonesian.

6. At this activities usually the teacher explains the lesson, get the students to read, dictate some short sentences and even giving games. 
7. Then in the last activity is post activity where at this time usually the teacher concludes the instructional material that has been presented, giving information for the lesson that will be discussed for the next meeting.

8. The students are motivated to learn English and do the tasks well.

\section{REFERENCES}

Allen,B.1965. Teaching English as Second Language.New York:Mc graw Hill Book Company.

Arifin, Imron. (ed) 1994. Penelitian Kualitatif dalam Ilmu-Ilmu Sosial dan Keagamaan. Malang: Kalimasada Press.

Arikunto,S.1998.prosedur penelitian suatu pendekatan praktek.jakarta:Pt Rineka Cipta.

Finnocero,M.1964.Teaching Children Foreign Language.New York:Mc graw Hill Book Company.

Furchan,F.1982.Pengantar penelitian Dalam Pendidikan.Surabaya:Usaha Nasional.

Hornby AS. .1995. Oxford Advances Learner's Dictionary Of Current English. London : Oxford University Press

K. Yin. Robert. 2002. desain Studi Kasus dan Metode.Jakarta PT Raja Grafindo Persada.

Kasbolah,k.1996.teaching and learning strategy.malang IKIP malang Allen,B. 1965. teaching English.

Moleong, J. Lexy. 2017. Metodologi Penelitian Kualitatif. Bandung: PT. Remaja Rosdakarya.

Sadtono,E.1996.Tes Dan Evalusi Pengajarn Bahasa.Malang:IKIP Malang. 